EESTI NSV TEADUSTE AKADEEMIA TOIMETISED. VII KOIDE

BIOLOOGILINE SEERIA. 1958, NR. 3

ИЗВЕСТИЯ АКАДЕМИИ НАУК ЭСТОНСКОИ ССР. ТОМ VII

СЕРИЯ БИОЛОГИЧЕСКАЯ, 1958, № 3

\title{
LEHMADELE VASIKAEAS SÖÖDETUD TÄISPIIMAKOGUSE OSATÄHTSUS NENDE KEHALISELE ARENGULE JA JOOUDLUSVÕIME KUJUNEMISELE
}

\author{
P. ARANDI, \\ põllumajandusteaduste doktor
}

Kuidas mōjutab lehmadele vasikaeas söödetud täispiimakogus nende kehalist arengut ja jōudlusvôime kujunemist - selle küsimuse uurimine ei paku üksnes elavat huvi, vaid tal on ka suur praktiline tähtsus.

Senini on olnud arvamused vasikatele vajaliku täispiimakoguse suhtes väga erinevad. Jurmaliati jt. $\left[{ }^{19}\right]$ ning Demtšenko $\left[{ }^{13}\right]$ andmeil kasutatakse Vene NFSV paljudes kolhoosides körgeid täispiimanorme - - kuni $600 \mathrm{~kg}$ vasika kohta. Vastupidisel seisukohal on Läti NSV Teaduste Akadeemia tegevliige prof. J. Berzin $\left[{ }^{12}\right]$; ta soovitab anda vasika kohta $60 \mathrm{~kg}$ täispiima. Ameerika Uhendriikides korraldațud katsed on näidanud, et noorkarja võib edukalt kasvatada, asendades täispiima keeruka koostisega jōusöödaseguga vōi sünteetilise piimaga $\left[{ }^{6}, 7,8\right]$.

Piimakarjal on Eesti NSV rahvamajanduses väljapaistev koht. Kõrgemate näitajate ning suurema rentaabluse saavutamiseks selles tootmisharus on vajalikud eksperimentaalselt pōhjendatud seisukohad vasika- ja üldse noorkarjakasvatuses, vastavalt vabariigi kolhooside ja sovhooside tootmistingimustele. Allpool esitatud katsete ülesandeks on näidata rikkalike ja mõōdukate piimanormide mõju noorveiste kasvule, sööda kasutamisele, täiskasvanud lehmade kehaehitusele ja jōudlusvōimele.

\section{Katsematerjal ja metoodika}

Kõnesolevad noorkarja kasvatamise katsed korraldati endises Eesti NSV Teaduste Akadeemia Loomakasvatuse ja Veterinaaria Instituudis aastatel 1949-1956. Käesolevas artiklis esitatakse resultaadid 1951.-1952. aastal komplekteeritud katserühmade kohta, keda kasvatati erinevail täispiimanormidel. Kuigi eri aastatel sündinud loomade rühmad pole õieti omavahel vōrreldavad, tuleb seda antud juhul siiski teha, arvestades nende ühesuguseid kasvatamistingimusi instituudi Tähtvere katsemajandis. Katseteks valitud eesti punast tõugu vasikad pōlvnesid kahelt puhtatõuliselt eliitpullilt (Pilot, AT-6538 ja Rein, ЭCAT-528) ja Tartu Lihakombinaadist ostetud teadmata tôulise kvaliteediga lehmades! (tabel 1).

Tabel

Andmeid katseteks valitud vasikate ja nende emade kohta

\begin{tabular}{|c|c|c|c|c|c|c|c|c|}
\hline \multirow[b]{2}{*}{ Rühm } & \multirow[b]{2}{*}{$\begin{array}{l}\text { Komp- } \\
\text { lekteeri- } \\
\text { mise } \\
\text { aasta }\end{array}$} & \multicolumn{2}{|c|}{ Vasikate } & \multicolumn{5}{|c|}{ Vasikate emade } \\
\hline & & $\begin{array}{l}\text { arv } \\
\text { rühmas }\end{array}$ & $\begin{array}{l}\text { keskmine } \\
\text { eluskaal } \\
\text { sündimi- } \\
\text { sel (kg) }\end{array}$ & $\begin{array}{l}\text { keskmine } \\
\text { elus- } \\
\text { kaal (kg) }\end{array}$ & $\begin{array}{l}\text { laktat- } \\
\text { sioon }\end{array}$ & $\begin{array}{l}\text { piimatoo- } \\
\text { dang } \\
\text { ( } 300 \mathrm{p} . \\
\text { vältel) }\end{array}$ & $\begin{array}{l}\text { piima- } \\
\text { rasva- } \\
\text { sus }(\%)\end{array}$ & $\begin{array}{c}\text { piima- } \\
\text { rasv } \\
(\mathrm{kg})\end{array}$ \\
\hline $\begin{array}{l}\text { A } \\
\text { B } \\
\text { C } \\
\text { D }\end{array}$ & $\begin{array}{l}1951 \\
1951 \\
1952 \\
1952\end{array}$ & $\begin{array}{r}8 \\
9 \\
10 \\
8\end{array}$ & $\begin{array}{l}33 \\
33 \\
34 \\
34\end{array}$ & $\begin{array}{l}528 \\
497 \\
508 \\
485\end{array}$ & $\begin{array}{l}\text { II }- \text { IV } \\
\text { II }- \text { IV } \\
\text { III-V } \\
\text { III }- \text { IV }\end{array}$ & $\begin{array}{l}3784 \\
3520 \\
3612 \\
3583\end{array}$ & $\begin{array}{l}3,54 \\
3,68 \\
3,53 \\
3,51\end{array}$ & $\begin{array}{l}134,0 \\
128,2 \\
127,5 \\
124,7\end{array}$ \\
\hline
\end{tabular}


Rühmad komplekteeriti kevadtalvel sündinud vasikatest analoogiliste katsete jaoks väljatöötatud metoodika alusel. Katsete plaanis nähti ette anda vasika kohta täispiima ja lôssi tabelis 2 esitatud skeemi järgi.

Tabel 2

Täispiima ja lõssi manustamine kilogrammides eríneva vanusega ja erinevatesse katserühmadesse kuuluvatele vasikatele

\begin{tabular}{|c|c|c|c|c|c|c|c|c|}
\hline \multirow{2}{*}{$\begin{array}{l}\text { Vasikate } \\
\text { vanus }\end{array}$} & \multicolumn{2}{|c|}{ A-rühm } & \multicolumn{2}{|c|}{ B-rühm } & \multicolumn{2}{|c|}{ C-rühm } & \multicolumn{2}{|c|}{ D-rühm } \\
\hline & $\begin{array}{l}\text { täis- } \\
\text { piim }\end{array}$ & lõss & $\begin{array}{l}\text { täis- } \\
\text { piim }\end{array}$ & lõss & $\begin{array}{l}\text { täis- } \\
\text { piim }\end{array}$ & lōss & $\begin{array}{l}\text { täis- } \\
\text { piim }\end{array}$ & lōss \\
\hline 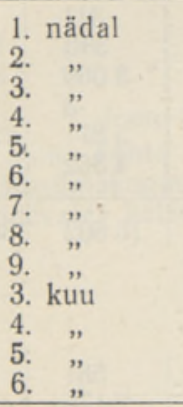 & $\begin{array}{l}6 \\
6 \\
6,5 \\
6,5 \\
6 \\
5 \\
4 \\
2 \\
1 \\
- \\
- \\
\\
\end{array}$ & $\begin{array}{c}- \\
\overline{-} \\
-1 \\
1 \\
2 \\
4,5 \\
6,5 \\
8 \\
10 \\
10 \\
9 \\
8 \\
4 \\
\end{array}$ & $\begin{array}{l}6 \\
7 \\
7 \\
7 \\
7 \\
7 \\
6,5 \\
6,5 \\
5 \\
3 \\
1 \\
- \\
- \\
\end{array}$ & $\begin{array}{l}= \\
= \\
= \\
= \\
= \\
= \\
-\end{array}$ & $\begin{array}{l}6 \\
6 \\
6 \\
5 \\
4 \\
3 \\
2 \\
1 \\
1 \\
- \\
- \\
- \\
-\end{array}$ & $\begin{array}{l}- \\
- \\
1 \\
2 \\
3 \\
6 \\
6 \\
8 \\
8 \\
8 \\
4 \\
2\end{array}$ & $\begin{array}{l}7 \\
8 \\
8 \\
8 \\
8 \\
7 \\
7 \\
5 \\
4 \\
2 \\
- \\
- \\
-\end{array}$ & $\begin{array}{r}- \\
\bar{z} \\
1 \\
2 \\
4 \\
6 \\
8 \\
10 \\
12 \\
12 \\
10 \\
5\end{array}$ \\
\hline Kokku & 301 & 1124 & 524 & - & 238 & 758 & 483 & 1351 \\
\hline
\end{tabular}

Heina ja haljassööta said kôik rühmad isu kohaselt. Mahlaka sööda, eriti söödapeedi annused normeeriti, sest kui loomad oleksid saanud seda vastavalt oma isule, oleksid nad tarbinud vähe kōrssööta. Jōusööt normeeriti vasikatele pärast 4.-5. elukuud, arvesse võttes neile antud täispiimakogust. Nimelt arvestati seda, et väiksema täispiimanormi saanud rühmades söövad vasikad ja mullikad puudujääva osa toidust pōhisöötadena. Kōiki loomi söödeti individuaalselt, kusjuures kuni 2 aasta vanuseni kaaluti neile etteantavad söödad ja viimaste jäägid iga päev (katsetes uuriti ühtlasi eesti punast tôugu noorveiste toitainetetarvet). C-rühmas anti osa jōusööta (kaerajahu) keedisena, A-rühmas söödeti vasikatele esimestel elukuudel kartulit püreena. Põhisöödad olid tüüpilised, keskmise kvaliteediga, sealhulgas hein jämedakõrreline ja osalt puitunud. Kasutatud söötade zootehniline täisanalüüs tehti omaaegse ENSV TA Loomakasvatuse ja Veterinaaria Instituudi piimanduse ja keemia laboratooriumis.

Pidamistingimused olid kõikides rühmades rahuldavad. Talveperioodil korraldati loomadele igapäevaseid jalutuskäike välisõhus. Suvel aga iaktilise söödakulutuse kindlakstegemise eesmärgil ei karjatatud loomi kuni 2 aasta vanuseni, vaid söödeti individuaalselt kas laudas või jooksuaeda paigutatud sõimedest ja künadest. Söötmisaegade vahepeal ja sooja ilmaga ka öösiti viibisid loomad vabas õhus.

Pärast poegimist söödeti loomi normide kohaselt, vôttes aluseks nende eluskaalu ja faktilise toodangu.

1957. aastal alustati täiendavaid katseid Väimela zoo-veterinaartehnikumis, kus katserühma täispiimanorm moodustas $130 \mathrm{~kg}$ ja lõssinorm $700 \mathrm{~kg}$. Nende katsete esialgsed tulemused on esitatud lühidalt peatükis «Katsetulemuste analüüs» (lk. 201).

\section{Söötade ja toitainete tarbimine erinevates katserühmades}

Looma kohta sünnist kuni 2 aasta vanuseni keskmiselt kulutatud söötade ja toitainete kogus on katserühmade järgi detailselt esitatud tabelis 3 . Kui võtta C-rühma faktiliselt kulutatud täispiimakogus 100 protsendiks, siis teistes rühmades saame vastavalt: $\mathrm{A}-113 \%, \mathrm{D}-169 \%$ ja B $209 \%$. Need andmed on näitlikult esitatud joonisel 1. Seega ületas katse- 


\section{Noorveiste söödakulutus sünnist kani 2 aasta vanuseni}

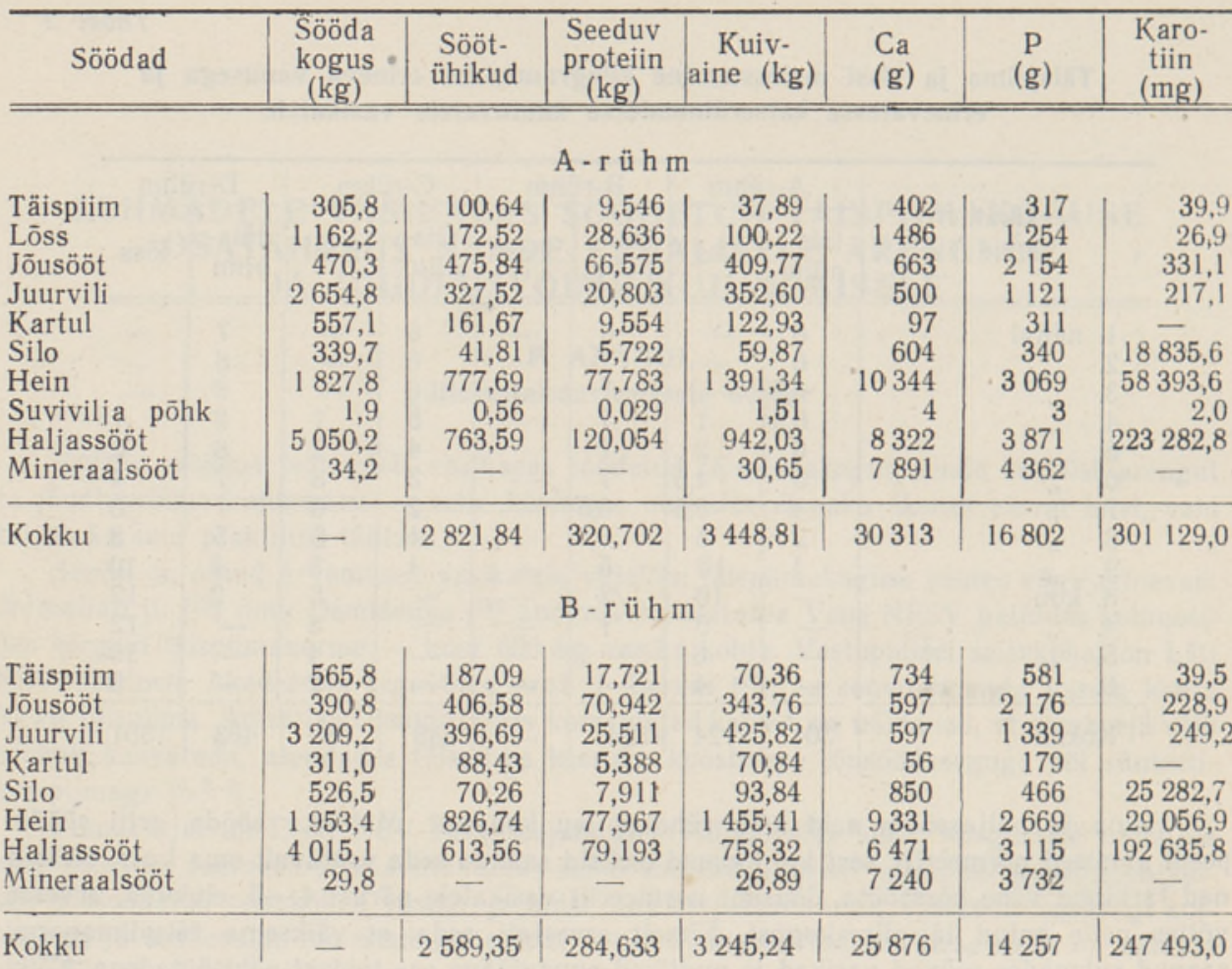

C - r üh m

\begin{tabular}{|c|c|c|c|c|c|c|c|}
\hline $\begin{array}{l}\text { Täispiim } \\
\text { Lõss } \\
\text { Kaerajahukeedis } \\
\text { Jōusööt } \\
\text { Juurvili } \\
\text { Kartul } \\
\text { Silo } \\
\text { Hein } \\
\text { Suvivilja pōhk } \\
\text { Haljassööt } \\
\text { Mineraalsööt }\end{array}$ & $\begin{array}{r}271,2 \\
810,5 \\
166,9 \\
605,2 \\
1913,0 \\
158,5 \\
1229,4 \\
1647,2 \\
68,9 \\
4962,8 \\
50,8\end{array}$ & $\begin{array}{r}91,21 \\
129,50 \\
26,33 \\
544,93 \\
227,05 \\
42,47 \\
168,55 \\
713,23 \\
16,73 \\
736,48 \\
-\end{array}$ & $\begin{array}{r}8,633 \\
24,711 \\
2,413 \\
73,820 \\
17,275 \\
2,764 \\
15,094 \\
66,717 \\
0,350 \\
109,941 \\
-\end{array}$ & $\begin{array}{r}34,69 \\
71,70 \\
24,79 \\
517,21 \\
244,54 \\
32,19 \\
234,12 \\
1230,16 \\
50,10 \\
1056,71 \\
45,92\end{array}$ & $\begin{array}{r}343 \\
968 \\
32 \\
693 \\
549 \\
14 \\
1689 \\
6046 \\
1171 \\
7621 \\
11128\end{array}$ & $\begin{array}{r}269 \\
706 \\
95 \\
3292 \\
753 \\
84 \\
783 \\
2495 \\
418 \\
4193 \\
6198\end{array}$ & $\begin{array}{r}34,4 \\
11,8 \\
14,2 \\
525,4 \\
66,2 \\
- \\
17000,5 \\
32573,1 \\
55,4 \\
58156,2 \\
-\end{array}$ \\
\hline Kokku & - & 2696,48 & $\begin{array}{l}321,718 \\
D-r \text { üh }\end{array}$ & 3542,13 & 30254 & 19286 & 108437,2 \\
\hline $\begin{array}{l}\text { Täispiim } \\
\text { Lõss } \\
\text { Jõusööt } \\
\text { Juurvili } \\
\text { Kartul } \\
\text { Silo } \\
\text { Hein } \\
\text { Suvivilja pōhk } \\
\text { Haljassööt } \\
\text { Mineraalsööt }\end{array}$ & $\begin{array}{r}459,5 \\
1330,4 \\
562,2 \\
1924,0 \\
273,7 \\
1287,0 \\
1523,7 \\
57,5 \\
5468,7 \\
42,1\end{array}$ & $\begin{array}{r}156,20 \\
212,78 \\
433,89 \\
288,29 \\
72,68 \\
170,33 \\
662,17 \\
13,98 \\
745,37 \\
-\end{array}$ & $\begin{array}{r}14,739 \\
41,261 \\
46,921 \\
28,506 \\
3,227 \\
16,834 \\
61,369 \\
0,295 \\
113,631 \\
-\end{array}$ & $\begin{array}{r}57,62 \\
118,72 \\
467,47 \\
191,91 \\
54,57 \\
251,79 \\
1109,09 \\
41,26 \\
1022,39 \\
37,95\end{array}$ & $\begin{array}{r}525 \\
1606 \\
754 \\
712 \\
30 \\
1528 \\
5449 \\
964 \\
8650 \\
9275\end{array}$ & $\begin{array}{r}422 \\
1176 \\
2251 \\
1589 \\
113 \\
871 \\
2875 \\
344 \\
6453 \\
5002\end{array}$ & $\begin{array}{r}61,4 \\
18,4 \\
422,8 \\
68,6 \\
-\overline{8} \\
27238,3 \\
30848,6 \\
45,7 \\
71173,3 \\
-\end{array}$ \\
\hline Kokku & - & $2.755,69$ & 326,783 & 3352,77 & 29493 & 21096 & 877,1 \\
\hline
\end{tabular}


tes kasutatud maksimaalne täispiimahulk minimaalse rohkem kui kahekordselt. Ligikaudu analoogilised vahekorrad olid piimarasva tarbimises. Nii moodustas looma kohta keskmiselt kulutatud piimarasvakogus rühmades A, B, C ja D vastavalt $11,2,20,9$ 9,98 ja $16,7 \mathrm{~kg}$.

Joon. 1.

Looma kohta kulutatud täispiimakoguse vōrdlus erinevates katserühmades.

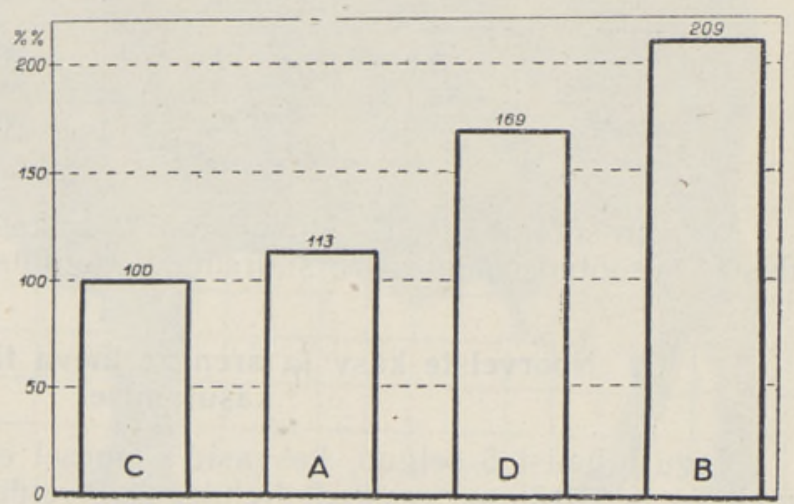

Vasikate jootmiseks·kasutatud erinev täisniima- ja lōssikogus mõjutasid söötmise taset kuni 6 kuu vanuseni. Mõõduka täisniimakogusega Crühmas tarbisid vasikad esimese 6 kuu jooksul 428 söötühikut ja 56 kğ seeduvat proteiini, B- ja D-rühmas vastavalt 538 ja 634 söötühikut ning 73 ja $83 \mathrm{~kg}$ seeduvat proteiini. Seega osutus söötmistase rikkalikult täisniima ja lõssi saanud rühmades 28 ja $48 \%$ kõrgemaks mõõduka täispiimakogusega C-rühmast, kus vasikad ei suutnud tarbida põhisöötasid ja esimestel elukuudel ka jõusöötasid piimaga võrdelises koguses. Mõõduka täisniimanormi saanud A-rühmas oli toifainete rohke tarbimine (601 söötühikut ja $81 \mathrm{~kg}$ seeduvat proteiini) tingitud suure koguse lõssi kasutamisest ja nähtavasti ka kartulipüree söötmisest. Vaatamata väga mitmesugusele söötmistasemele kuni 6 kuu vanuseni, pole rühmadevahelised erinevused kahe esimese eluaasta kestel kulutatud toitainete kogusumma poolest suured.

Noorveise kohta sünnist kuni 2 aasta vanuseni kasutatud keskmine söötühikute hulk kõikus 2589 (B-rühm) - 2822 (A-rühm) piirides. Seega oli erinevus üldises söötmistasemes suurim A- ja B-rühma vahel $(8.3 \%)$; B-, C- ja D-rühma vahel oli erinevus $1-2 \%$. Seeduvat proteiini sai B-rühm mõnevõrra vähem teistest $(285 \mathrm{~kg})$ : ülejäänud rühmades olid erinevused proteiini osas tähtsusetud (esines kōikumisi $321--327 \mathrm{~kg}$ piirides). Väiksem proteiinikogus B-rühmas oli tingitud rikkaliku täispiimanormi tõttu jõusööda hulga piiramisest ia lõssi väliajätmisest ratsioonidest. Kuiv- ja mineraalainete suhtes olid rühmadevahelised erinevused umbes samasugused nagu üldises söötmistasemes. Karotiini said kōik vasikad enam-vähem normi kohaselt, A-rühmas aga märgatavalt rohkem.

Mullikaid söödeti pärast teist eluaastat kuni esimese poegimiseni kõigis rühmades ühteviisi. Talveperioodil koosnes nende päevane ratsioon $4-5 \mathrm{~kg}$ põld- või kultuurniiduheinast, $2-3 \mathrm{~kg}$ suviviljapõhust, $10-15 \mathrm{~kg}$ juurviljast või $8-10 \mathrm{~kg}$ silost ja $1-1,5 \mathrm{~kg}$ jõusöödast. Ratsiooni toiteväärtus moodustas 5,5-6,0 söötühikut, milles sisaldus $550-650$ g seeduvat proteiini. Suveperioodil karjatati kõiki rühmi kultuurrohumaadel ja ädalapõldudel. Sõltuvalt esmakordse poegimise ajast kujunes keskmine toitainete kulutus looma kohta järgmiseks; 


\begin{tabular}{c|c|c|c|c}
\hline \multirow{2}{*}{ Rühm } & \multicolumn{2}{|c|}{$\begin{array}{c}\text { Kahe aasta vanusest kuni } \\
\text { esimese poegimiseni }\end{array}$} & \multicolumn{2}{c}{$\begin{array}{c}\text { Sünnist kuni esimese } \\
\text { poegimiseni }\end{array}$} \\
\cline { 2 - 3 } & söötühikuid & $\begin{array}{c}\text { seeduvat } \\
\text { proteini (kg) }\end{array}$ & söötühikuid & $\begin{array}{c}\text { seeduvat } \\
\text { proteiini (kg) }\end{array}$ \\
& & 97,69 & 3614,6 & 418,39 \\
A & 797,2 & 133,95 & 3603,9 & 418,58 \\
B & 1014,6 & 140,85 & 3925,9 & 462,57 \\
C & 1229,5 & 87,63 & 3399,3 & 414,41 \\
D & 643,0 & & &
\end{tabular}

Kõrgem söötmistase C-rühmas kuni 2 aasta vanuseni on tingitud koduste jõ̃usöötade mõnevõrra suuremast osatähtsusest ratsioonides.

\section{Noorveiste kasv ja areng erineva täispiimakoguse kasutamisel}

Nagu tabelist 5 selgub, kasvasid esimesel eluaastal kõige intensiivsemalt A- ja D-rühma vasikad. Nendega võrreldes olid ööpäevased kaaluiibed B-rühmas üle $100 \mathrm{~g}$, C-rühmas aga rohkem kui $200 \mathrm{~g}$ väiksemad. Tingituna A- ja D-rühma kiiremast kasvust ületas vasikate keskmine eluskaal aasta vanuselt eliitrekordklassi nõudeid $11-14 \%$.

Loomade kehakaalude ja ööpäevaste kaaluiivete dünaamika

Tabel 5

\begin{tabular}{|c|c|c|c|c|c|c|c|c|c|c|c|}
\hline \multirow[b]{2}{*}{ 品 } & \multicolumn{6}{|c|}{ Eluskaal (kg) } & \multicolumn{5}{|c|}{ Oöpäevased kaaluiibed (g) } \\
\hline & 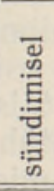 & 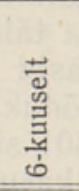 & 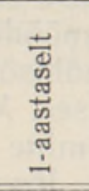 & 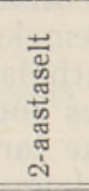 & 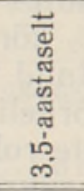 & 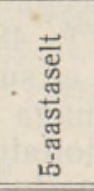 & 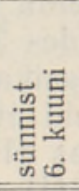 & 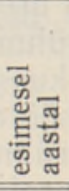 & 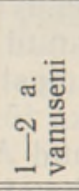 & 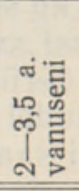 & 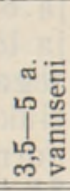 \\
\hline A & 33 & 166,5 & 283,3 & 467,3 & 482,1 & 518,5 & 731 & 686 & 504 & 43 & 100 \\
\hline B & 33 & 159,9 & 241,8 & 382,6 & 496,7 & 549 & 701 & 572 & 38 & 313 & 144 \\
\hline $\mathrm{C}$ & 34 & 142,9 & 210,9 & 378,0 & 494,1 & 559,5 & 63 & 457 & 458 & 318 & 179 \\
\hline D & 34 & 183,4 & 290,5 & 412,5 & 501,2 & 533,3 & 819 & 692 & 334 & 243 & 88 \\
\hline
\end{tabular}

B-rühmas ulatusid vasikate eluskaalud eliitklassi tasemele, C-rühmas vastasid nad keskmiselt II klassi nõudeile.

Teisel eluaastal saavutasid mullikad kõige kõrgemad kaaluiibed A- ja C-rühmas, ületades teisi rühmi $19-51 \%$ võrra. Nii saavutasid 2 -aastased A-rühma mullikad, võrreldes teiste rühmadega, kõrgeima eluskaalu, ületades eliitrekordklassi nõudeid $18 \%$ võrra. Eliitrekordklassi taseme ületas ka D-rühm 4,5\% võrra. B-rühm jäi keskmisè eluskaalu poolest eliitklassi, C-rühm aga aeglase kasvu tōttu esimesel eluaastal I klassi tasemele.

Pärast teist eluaastat toimus kõige kiirem kasv C-rühmas, mille tõttu lehmade eluskaal tõusis 5. eluaastal keskmiselt $560 \mathrm{~kg}$-ni. Mitmed loomad kaalusid isegi kuni $600 \mathrm{~kg}$. Nagu tabelist 5 selgub, kompenseerus mahajäämus C-rühma noorveiste kehakaalus 5. eluaastaks täiesti. Vaatamata erinevaile söötmistingimustele ja neist olenevalt ka- erinevale kasvule, ületas täiskasvanud 5-aastaste lehmade kehakaal kôigis rühmades eliitrekordklassi nõuded. Ka nende eksterjöörimõõdud, mille kohta annab ülevaate tabel 6, näitasid, et lehmad olid kõigis rühmades hästi arenenud (joonised 2-5).

Vasikaeas rikkalikult täispiima ja lõssi saanud D-rühma lehmadel oli turja kõrgus mõnevõrra suurem, Laiusmõōtudelt ja kehaehituse tugevu- 


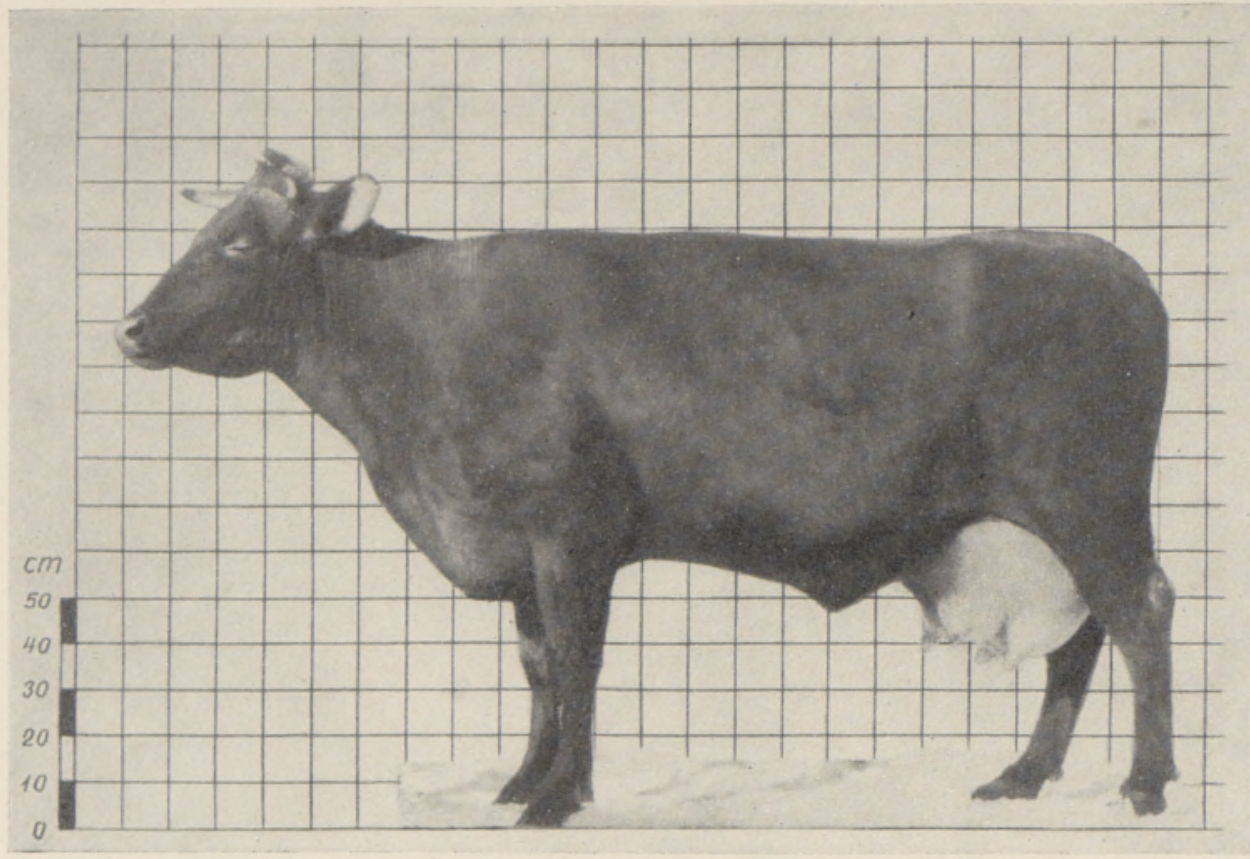

Joon. 2. A-rühma lehm nr. 219, eluskaal 5-aastaselt $531 \mathrm{~kg}$, toodang III laktatsioonil (300 p. jooksul) $4916 \mathrm{~kg}$ piima ja $173,9 \mathrm{~kg}$ piimarasva.

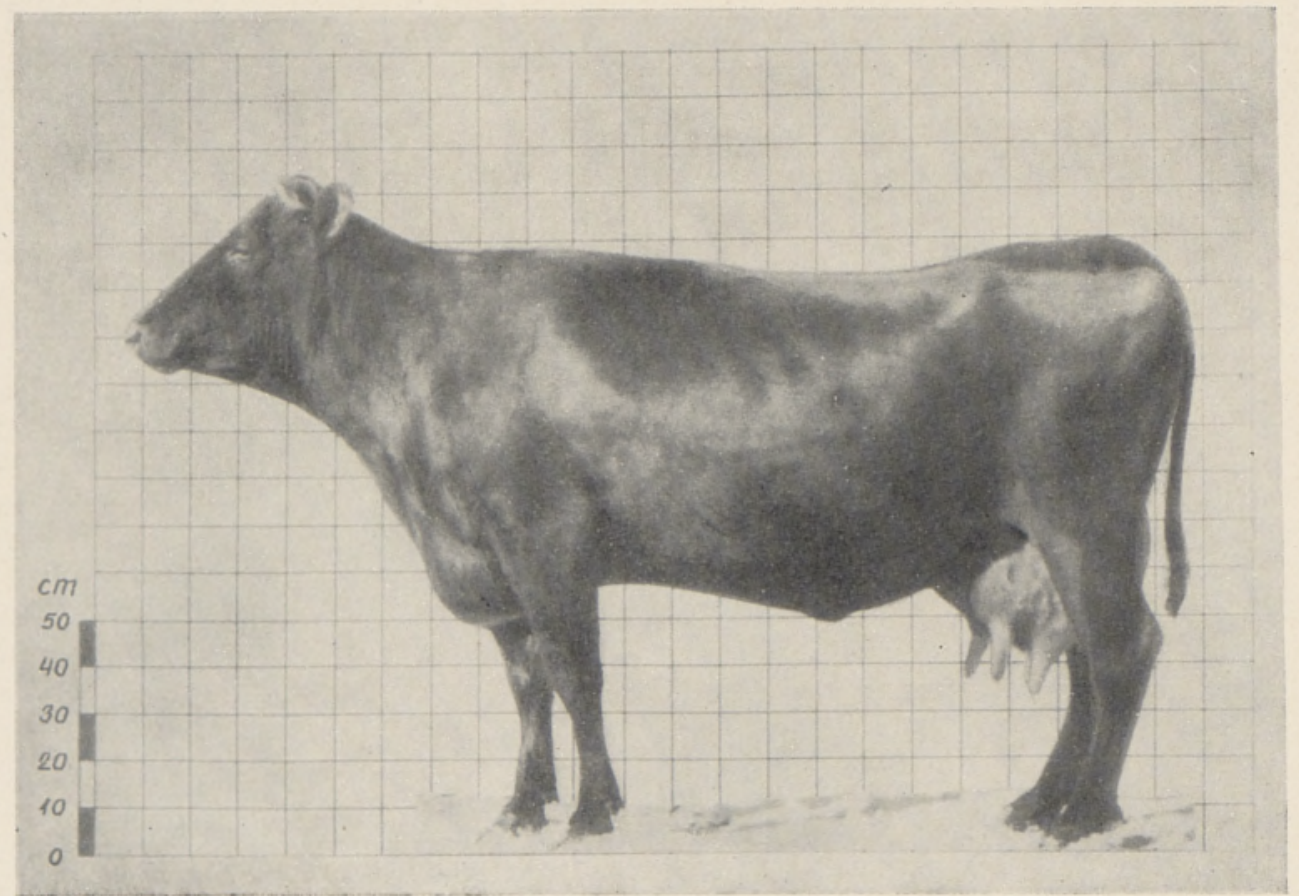

Joon. 3. B-rühma lehm nr. 254, eluskaal 5 -aastaselt $512 \mathrm{~kg}$, toodang III laktatsioonil (300 p. jooksul) $4425 \mathrm{~kg}$ piima ja $168,4 \mathrm{~kg}$ piimarasva. 


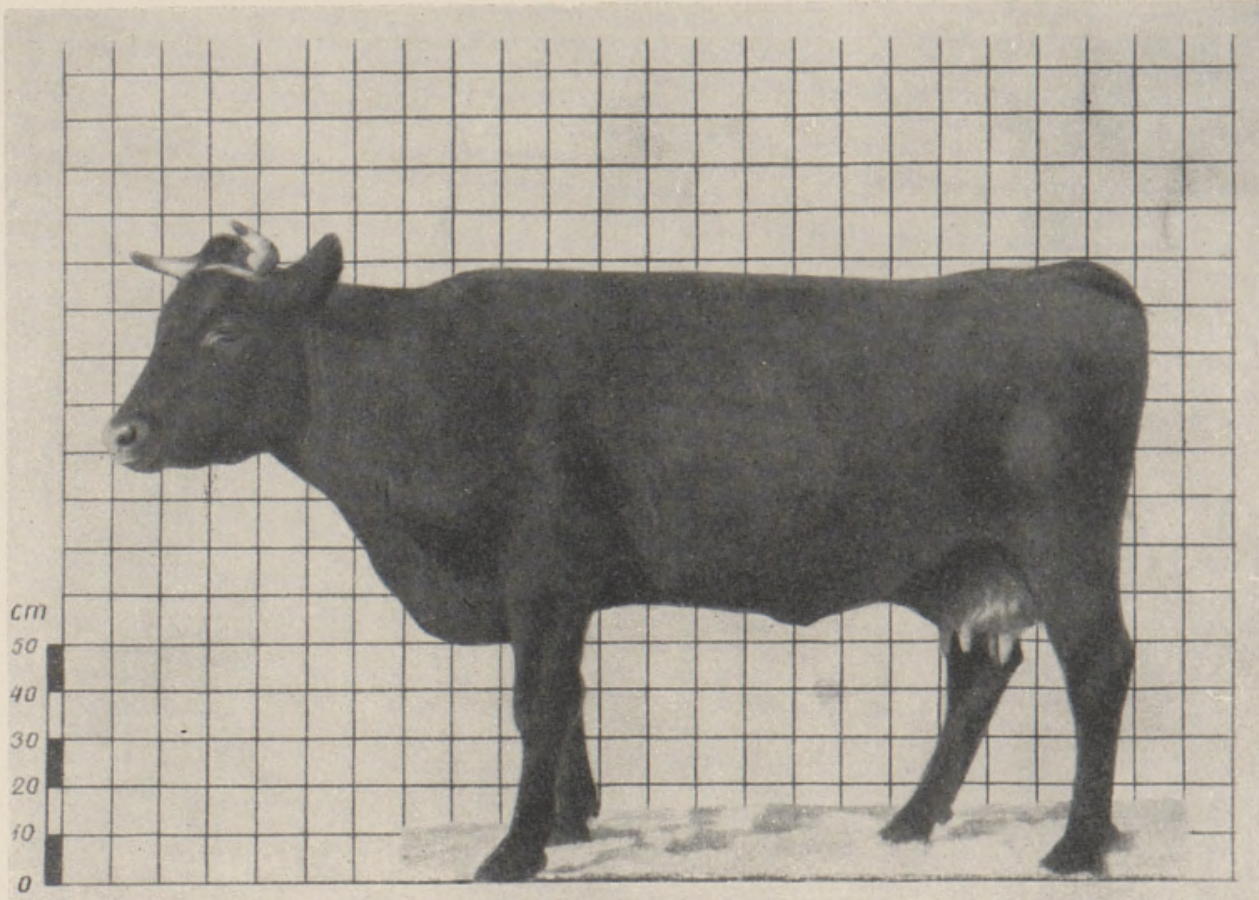

Joon. 4. C-rühma lehm nr. 303, eluskaal 5-aastaselt $624 \mathrm{~kg}$, toodang II laktatsioonil (300 p. jooksul) $5000 \mathrm{~kg}$ piima ja $189,9 \mathrm{~kg}$ piimarasva.

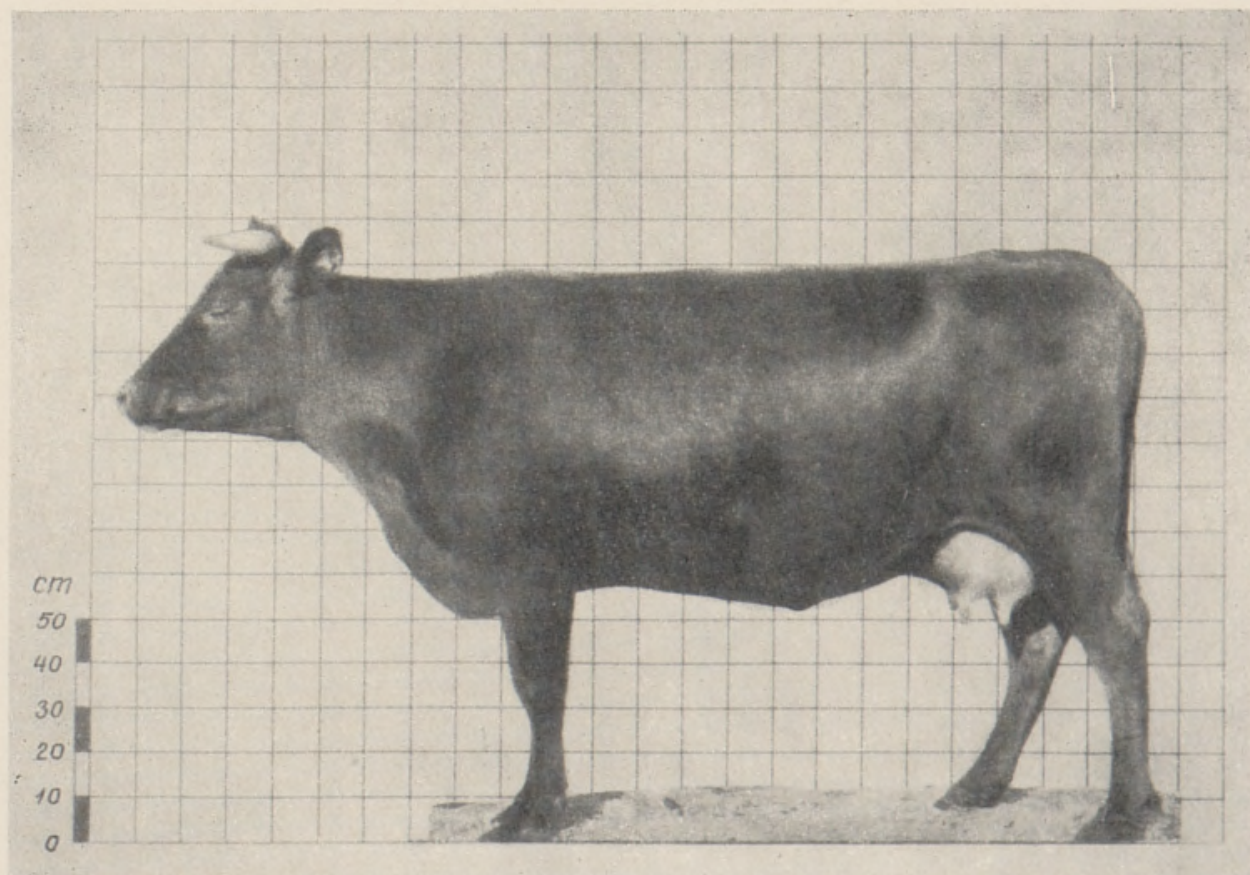

Joon. 5. D-rühma lehm $\mathrm{nr}$. 279, eluskaal 5 -aastaselt $523 \mathrm{~kg}$, toodang II laktatsioonil (300 p. jooksul) $3433 \mathrm{~kg}$ piima ja $147,4 \mathrm{~kg}$ piimarasva. 
selt ei jäänud D-rühmast sugugi maha, vaid mõnevõrra isegi ületasid teda vasikaeas mõõdukalt täispiima saanud C-rühma lehmad.

Tabel 6

Iseloomustavamaid eksterjöörimõõte 5-aastastel lehmadel (sentimeetrites)

\begin{tabular}{c|c|c|c|c|c|c|c}
\hline Rühm & $\begin{array}{c}\text { Turja } \\
\text { kôrgus }\end{array}$ & $\begin{array}{c}\text { Rinna } \\
\text { sügavus }\end{array}$ & $\begin{array}{c}\text { Rinna } \\
\text { laius }\end{array}$ & $\begin{array}{c}\text { Laudja laius } \\
\text { puusanuk- } \\
\text { kide kohal }\end{array}$ & $\begin{array}{c}\text { Kere põik- } \\
\text { pikkus } \\
\text { (mōõdetud } \\
\text { kepiga) }\end{array}$ & $\begin{array}{c}\text { Rinna } \\
\text { ümber- } \\
\text { mõōt }\end{array}$ & $\begin{array}{c}\text { Kämbla } \\
\text { ümber- } \\
\text { mõõt }\end{array}$ \\
\hline \hline & 130,0 & 67,5 & 42,7 & 54,0 & 154,3 & 188,0 & 18,4 \\
A & 129,8 & 67,8 & 40,0 & 52,8 & 155,2 & 189,0 & 18,2 \\
C & 128,2 & 68,0 & 43,6 & 53,3 & 156,8 & 190,1 & 18,7 \\
D & 132,0 & 67,0 & 41,5 & 53,4 & 154,8 & 188,2 & 18,3
\end{tabular}

Arvesse vōttes loomade arengut, viidi A- ja D-rühmas esmakordne paaritamine läbi keskmiselt 18--18,5 kuu vanuselt. Selleks ajaks tõusis mullikate eluskaal A-rühmas umbes 400 kilogrammini, D-rühmas ligi 370 kilogrammini. Mõnevõrra aeglasema kasvu ja arenemise tõttu paaritati B- ja C-rühma mullikaid $21,1-21,5$ kuuselt, eluskaaluga $360-380 \mathrm{~kg}$. Peale mõne üksikjuhu toimus tiinestumine esimesel paaritamisel normaalselt. Kõigis rühmades olid vastsündinud vasikad normaalselt arenenud ja nende sünnikaalud kõikusid $30-35 \mathrm{~kg}$ piirides.

\section{Lehmade söödakulutus ja jõudlusvõime esimeste! lüpsiperioodidel}

Söödakulutuse andmed laktatsiooniperioodide vältel on toodud tabelis 7. Siit selgub, et söötmise tase Tähtvere katsemajandis oli keskpärane,

Söödakulutus laktatsiooniperioodide vältel (tsentnerites)

Tabel 7

\begin{tabular}{|c|c|c|c|c|c|c|c|c|}
\hline \multirow[b]{2}{*}{$\begin{array}{l}\text { Lak- } \\
\text { tat- } \\
\text { sioon }\end{array}$} & \multirow[b]{2}{*}{$\begin{array}{l}\text { Loo- } \\
\text { made } \\
\text { arv }\end{array}$} & \multirow[b]{2}{*}{$\begin{array}{l}\text { Jõu- } \\
\text { söödad }\end{array}$} & \multirow[b]{2}{*}{ Hein } & \multirow[b]{2}{*}{ Pōhk } & \multirow[b]{2}{*}{$\begin{array}{c}\text { Mahlakad } \\
\text { söödad }\end{array}$} & \multirow{2}{*}{$\begin{array}{l}\text { Karja- } \\
\text { maa- ja } \\
\text { haljas- } \\
\text { sööt }\end{array}$} & \multicolumn{2}{|c|}{ Kokku } \\
\hline & & & & & & & $\begin{array}{c}\text { sööt- } \\
\text { ühikuid }\end{array}$ & \begin{tabular}{|c|}
$\begin{array}{c}\text { seeduvat } \\
\text { proteiini } \\
(\mathrm{kg})\end{array}$ \\
\end{tabular} \\
\hline & \multicolumn{8}{|c|}{$A-r u ̈ h m$} \\
\hline $\begin{array}{l}\text { I } \\
\text { II } \\
\text { III } \\
\text { IV }\end{array}$ & $\begin{array}{l}8 \\
6 \\
5 \\
5\end{array}$ & $\begin{array}{r}9,93 \\
11,06 \\
10,44 \\
13,91\end{array}$ & $\begin{array}{l}9,53 \\
7,16 \\
8,24 \\
9,51\end{array}$ & $\begin{array}{l}5,72 \\
4,72 \\
3,54 \\
1,92\end{array}$ & $\begin{array}{l}60,76 \\
62,33 \\
42,77 \\
39,68\end{array}$ & $\begin{array}{l}41,22 \\
79,24 \\
81,08 \\
69,35\end{array}$ & $\begin{array}{l}2934 \\
3480 \\
3418 \\
3735\end{array}$ & $\begin{array}{l}390,3 \\
414,7 \\
422,6 \\
589,2\end{array}$ \\
\hline \multicolumn{9}{|c|}{$\mathrm{B}-\mathrm{r}$ ü h m } \\
\hline $\begin{array}{l}\text { I } \\
\text { II } \\
\text { III } \\
\text { IV }\end{array}$ & $\begin{array}{l}8 \\
6 \\
6 \\
5\end{array}$ & $\begin{array}{r}12,86 \\
12,03 \\
9,64 \\
11,53\end{array}$ & $\begin{array}{r}9,85 \\
5,68 \\
8,26 \\
10,67\end{array}$ & $\begin{array}{l}5,43 \\
2,78 \\
2,43 \\
2,21\end{array}$ & \begin{tabular}{|l}
65,48 \\
60,59 \\
51,31 \\
53,24
\end{tabular} & $\begin{array}{l}26,83 \\
57,16 \\
70,71 \\
71,19\end{array}$ & $\begin{array}{l}3136 \\
3211 \\
3358 \\
3870\end{array}$ & $\begin{array}{l}420,2 \\
409,3 \\
393,7 \\
544,2\end{array}$ \\
\hline \multicolumn{9}{|c|}{$\mathrm{C}-\mathrm{r}$ ü h m } \\
\hline $\begin{array}{r}\text { I } \\
\text { II } \\
\text { III }\end{array}$ & $\begin{array}{r}10 \\
10 \\
6\end{array}$ & $\begin{array}{r}11,86 \\
7,34 \\
13,08\end{array}$ & $\begin{array}{l}5,58 \\
8,22 \\
9,72\end{array}$ & $\begin{array}{l}2,94 \\
3,71 \\
2,53\end{array}$ & $\begin{array}{l}42,17 \\
49,88 \\
46,82\end{array}$ & $\begin{array}{l}58,89 \\
75,70 \\
77,29\end{array}$ & $\begin{array}{l}3004 \\
3180 \\
3960\end{array}$ & $\begin{array}{l}401,9 \\
385,5 \\
578,0\end{array}$ \\
\hline \multicolumn{9}{|c|}{$\mathrm{D}-\mathrm{r} \ddot{\mathrm{u} h \mathrm{~m}}$} \\
\hline $\begin{array}{r}\text { I } \\
\text { II } \\
\text { III }\end{array}$ & $\begin{array}{l}8 \\
6 \\
4\end{array}$ & $\begin{array}{r}11,15 \\
8,07 \\
8,09\end{array}$ & $\begin{array}{l}5,58 \\
7,67 \\
7,83\end{array}$ & $\begin{array}{l}3,45 \\
3,51 \\
3,80\end{array}$ & $\begin{array}{l}38,69 \\
51,52 \\
45,88\end{array}$ & $\begin{array}{l}63,43 \\
74,39 \\
65,33\end{array}$ & $\begin{array}{l}2957 \\
2960 \\
3792\end{array}$ & $\begin{array}{l}390,2 \\
347,6 \\
398,9\end{array}$ \\
\hline
\end{tabular}


võrreldes vabariigi sovhoosidega. Rohkesti kasutati jõusööta, mis moodustas laktatsiooniperioodide vältel (I-III laktatsioonini) kulutatud söötühikute kogusummast $27-38 \%$. Iga kilogrammi piima tootmiseks kulus jõusööta esimesel laktatsiooniperioodil 300-315 g, hiljem (II, III ja IV laktatsiooniperioodil) 250-320 g. Põhisöötade osa, võrreldes kõigi lüpsiperioodide vältel kasutatud söötühikute hulgaga, oli järgmine: heinal $8-15 \%$, põhul $2-6 \%$, mahlakatel söötadel $17-25 \%$, karjamaa- ja haljassöötadel $12-37 \%$. Kinnisperioodidel (kestusega $51-72$ päeva) manustati päevas söötasid, mille toiteväärtus oli 5,6-6,5 söötühikut, ja 700 -$800 \mathrm{~g}$ seeduvat proteini.

Andmeid lehmade jõudlusvõime kohta I-IV laktatsioonini esitab tabel 8. Esimesel lüpsiperioodil andsid A- ja D-rühma lehmad võrdlemisi madala toodangu (vastavalt 3163 ja $3075 \mathrm{~kg}$ ). Teisel laktatsioonil tõusis toodang kolmes esimeses rühmas $12-18 \%$, D-rühmas ainult $4 \%$. Kolmandal laktatsioonil ületasid C-rühma lehmad keskmise toodangu poolest teisi $16-29 \%$ võrra. Kahel C-rühma loomal küündis piimatoodang üle $6000 \mathrm{~kg}$ jla neilt saadi üle $200 \mathrm{~kg}$ piimarasva. Kõige nõrgema piimatoodanguga olid D-rühma lehmad.

Tabel 8

Piimajõudlus I-IV laktatsioonil (keskmiselt looma kohta kilogrammides 300 päeva vältel)

\begin{tabular}{|c|c|c|c|c|c|c|c|c|}
\hline \multirow[b]{2}{*}{ Rühm } & \multirow[b]{2}{*}{$\begin{array}{l}\text { Laktat- } \\
\text { sioon }\end{array}$} & \multirow{2}{*}{$\begin{array}{l}\text { Loo- } \\
\text { made } \\
\text { arv }\end{array}$} & \multicolumn{2}{|c|}{ Piimatoodang (kg) } & \multicolumn{2}{|c|}{ Piimarasvasus (\%) } & \multicolumn{2}{|c|}{ Piimarasv (kg) } \\
\hline & & & $\begin{array}{l}\text { kesk- } \\
\text { mine }\end{array}$ & kõikumised & $\begin{array}{l}\text { kesk- } \\
\text { mine }\end{array}$ & kōikumised & $\begin{array}{l}\text { kesk- } \\
\text { mine }\end{array}$ & kōikumised \\
\hline A & $\begin{array}{l}\text { I } \\
\text { II } \\
\text { III } \\
\text { IV }\end{array}$ & $\begin{array}{l}8 \\
6 \\
6 \\
5\end{array}$ & $\begin{array}{l}3163 \\
3708 \\
3906 \\
4282\end{array}$ & $\begin{array}{l}2042-4245 \\
2590-4641 \\
2832-4916 \\
3338-5054\end{array}$ & $\begin{array}{l}3,78 \\
3,69 \\
3,89 \\
3,68\end{array}$ & $\begin{array}{l}3,31-3,85 \\
3,49-3,87 \\
3,54-4,36 \\
3,61-4,08\end{array}$ & $\begin{array}{l}119,6 \\
136,8 \\
151,9 \\
157,6\end{array}$ & $\begin{array}{r}76,8-150,3 \\
96,3-175,3 \\
110,9-181,1 \\
123,4-182,3\end{array}$ \\
\hline B & $\begin{array}{l}\text { I } \\
\text { II } \\
\text { III }\end{array}$ & $\begin{array}{l}8 \\
6 \\
5 \\
5\end{array}$ & $\begin{array}{l}3499 \\
4146 \\
4125 \\
4642\end{array}$ & $\begin{array}{l}3187-4425 \\
3576-5128 \\
3253-5445 \\
3554-5923\end{array}$ & $\begin{array}{l}3,95 \\
3,92 \\
4,11 \\
3,82\end{array}$ & $\begin{array}{l}3,44-4,46 \\
3,54-4,41 \\
3,73-4,91 \\
3,50-4,42\end{array}$ & $\begin{array}{l}138,2 \\
162,5 \\
169,5 \\
177,8\end{array}$ & $\begin{array}{c}125,0-152,3 \\
143,0-181,3 \\
148,7-203,4 \\
148,5-213,2\end{array}$ \\
\hline C. & $\begin{array}{r}\text { I } \\
\text { II } \\
\text { III }\end{array}$ & $\begin{array}{r}10 \\
10 \\
6\end{array}$ & $\begin{array}{l}3380 \\
3798 \\
4917\end{array}$ & $\begin{array}{l}2307-4856 \\
2139-5010 \\
3770-6708\end{array}$ & $\begin{array}{l}3,66 \\
3.85 \\
3,80\end{array}$ & $\begin{array}{l}3,47-4,18 \\
3,27-4,27 \\
3,42-4,44\end{array}$ & $\begin{array}{l}123,7 \\
146,1 \\
186,8\end{array}$ & $\begin{array}{r}85,8-182,7 \\
81,2-194,7 \\
139,8-235,8\end{array}$ \\
\hline D & $\begin{array}{r}\text { I } \\
\text { III }\end{array}$ & $\begin{array}{l}8 \\
6 \\
4\end{array}$ & $\begin{array}{l}3075 \\
3200 \\
3486\end{array}$ & $\begin{array}{l}2763-3454 \\
2772-3800 \\
2618-4113\end{array}$ & $\begin{array}{l}3,71 \\
4,13 \\
4,05\end{array}$ & $\begin{array}{l}3,65-4,06 \\
3,72--4,43 \\
3,80-4,26\end{array}$ & $\begin{array}{l}114,1 \\
132,1 \\
141,2\end{array}$ & $\begin{array}{l}110,5-140,1 \\
103,1-156,3 \\
107,1-163,1\end{array}$ \\
\hline
\end{tabular}

Lehmade jõudlusandmete võrdlemisel oma emade piimatoodanguga (tab. 1) ilmneb, et need on esimeste puhul enamasti tunduvalt kõrgemad (III-ndate ja IV-ndate laktatsioonide võrdlemisel). A-, B- ja C-rühma lehmad ületasid oma emasid piimatoodangult $5-36 \%$ ja piimarasvasuselt $0,27-0,43 \%$. D-rühma lehmade piimatoodang oli ligikaudu ühesugune nende emadega, kuid piimarasvasus oli neil märgatavalt kõrgem.

\section{Noorkarja söötmise ökonoomikast}

Tabelis 3 toodud faktilise söödakulutuse ja söötade tootmishinna (omahinna) alusel tehtud kalkulatsioonid näitavad, et sünnist kuni 2 aasta vanuseni kasutatud keskmine söötade väärtus looma kohta moodustas Arühmas 1279 rubla, B-rühmas 1457, C-rühmas 1207 ja D-rühmas 1396 rubla. Aliates teisest eluaastast kuni lehmaks saamiseni (esmakordse poe- 
gimiseni) moodustas kasutatud söötade omahind A-, B-, C- ja D-rühmas vastavalt $311,323,381$ ja 225 rubla. Järelikult kulutati ühe lehma kasvatamiseks sünnist kuni esmakordse poegimiseni söötasid alljärgnevas väärtuses: A-rühmas 1590 rbl., B-rühmas 1780 rbl., C-rühmas 1588 rbl. ja D-rühmas 1621 rbl.

Seega, nagu näitab B- ja C-rühma võrdlemine, osutus söötade maksumus majandi tootmishinnas kõrge täispiimanormi kasutamisel ilma kooritud piimata ühe looma kohta maksimaalselt 200 rubla võrra kallimaks. See summa üksi ei iseloomusta veel täielikult täispiima rohke kasutamise ebaratsionaalsust, vaid samaaegselt tuleb jälgida ka produktide kulutust.

Võrreldes B- ja D-rühmaga kasutati täispiima A- ja C-rühmas looma kohta $154-296 \mathrm{~kg}$ vähem, mis vastab umbes $5,7-10,9 \mathrm{~kg}$ piimarasvale. Sellise koguse piima või piimarasva säästmisel iga üleskasvatatud vasika pealt on küllaltki suur tähtsus elanikkonna toitlustamisel, eriti kui arvestada, et vabariigis jäetakse iga aasta kasvama $70000-80000$ vasikat. Seejuures tuleb arvestada, et C-rühma noorveiste eluskaalud jäid I ja II klassi tasemele, mis tõuloomana müües alandab tublisti nende hinda. Kuid piimalehmadena nad ei osutunud halvemaks vasikaeas rikkaliku täispiimanormiga söödetud loomadest. Rikkalikul söötmisel heakvaliteediliste pōhisöötadega oleks tõenäoliselt võinud ka C-rühmas saavutada eliitrekordklassi taseme.

\section{Katsetulemuste analüüs}

Eespool selgus, et erinevates katserühmades kulutati vasika kohta keskmiselt $271-567 \mathrm{~kg}$ täispiima. seejuures $10-21 \mathrm{~kg}$ piimarasva. Tingituna peamiselt põhisöötade puudulikust kvaliteedist tarbisid mõõduka täispiimanormiga üleskasvatatud C-rühma vasikad kuni 6 kuu vanuseni toitaineid $28-48 \%$ vähem kui teistes rühmades ja langesid oma madala eluskaalu tõttu aasta vanuselt II boniteerimisklassi. Suurema täispiima- ja lõssinormiga kasvatatud rühmades (välja arvatud B-rühm) ületas vasikate eluskaal eliitrekordklassi nõuded. Normaalsetes söötmis- ja pidamistingimustes kompenseerus mahajäämus C-rühma loomade kasvus ja arengus, alates teisest eluaastast. 5-aastaste lehmade eluskaal erinevates katserühmades kõikus 519 (A-rühm) - 560 kg (C-rühm) piirides, kusjuures loomade kehalises arengus polnud olulisi rühmadevahelisi erinevusi.

I laktatsiooniperioodil olid keskmised piima- ja piimarasvatoodangud B-rühmas 3499 ja $138,2 \mathrm{~kg}$ ning C-rühmas 3380 ja $123,7 \mathrm{~kg}$. Need näitajad on $3,3-17,4 \%$ kõrgemad kui A- ja D-rühmas, mis peamiselt on seletatav B- ja C-rühma mullikate mõnevõrra hilisema paaritamisega. II laktatsiooniperioodil ületasid A-, B- ja C-rühm jõudlusvõime poolest D-rühma $3.4-22,8 \%$ võrra. B- ja C-rühmas tootsid paremad lehmad üksiku kohta üle $5000 \mathrm{~kg}$ piima ja üle $180 \mathrm{~kg}$ piimarasva. Järelikult ei avaldanud vasikatele söödetud erinev täispiimakogus, samuti nende erinev kasvukiirus esimesel eluaastal täiskasvanud lehmade jõudlusvõimele ja kehalisele arengule märgatavat mõiu. Võib arvata, et tugevamal söötmisel lüpsiperioodide vältel ja parema tõulise kvaliteedi puhul oleks lehmade jõudlusvõime olnud kõigis rühmades üldiselt kõrgem.

Võrdluseks omadele katsetulemustele märgime, et rootsi autorite [2, s] andmeil avaldab noorveiste üleskasvatamine rikkalike täispiimakogustega (III laktatsioonist alates) nende suurusele ja jõudlusvõimele hiliem vähe mõju. kui nende söätmine, alates esmakordsest poegimisest, on küllaldane.

Vändra katsejaama andmeil $\left[{ }^{4}\right]$ on nende paremad lehmad saanud vasikana $250 \mathrm{~kg}$ täispiima, kuid rikkalikult lõssi (skeemi kohaselt kuni $1870 \mathrm{~kg})$. 
Inglismaal ja Ameerika Ohendriikides kasutatakse noorkarja kasvatamisel võrdlemisi vähe täispiima $(120-130 \mathrm{~kg})$ ja loomi söödetakse üldiselt mõõdukalt ["]. On tehtud edukaid katseid kasvatada vasikaid isegi ilma täispiimata $\left[^{7}\right]$, piirdudes vaid ternespiimaga.

Enamik NSV Liidu vastava ala eriteadlasi $\left[{ }^{14-18}\right]$ peab aga vajalikuks noorkarja intensiivset kasvatamist, mistōttu praktikas kasutataksegi kõrgeid täispiimanorme.

Mitmes Eesti NSV tõukarjasovhoosis (Triigi, Udeva jt.), samuti Tähtvere katsemajandis kasutati mõnede rühmade vasikate kasvatamisel kõrgeid täispiimanorme $(600-800 \mathrm{~kg})$. Oldiselt peeti heaks tulemuseks, kui vasikate ööpäevased kaaluiibed kuni 6 kuu vanuseni moodustasid 1000-$1200 \mathrm{~g}$ (selliste näitajate saavutamise eest premeeriti vasikatalitajaid). Intensiivsel kasvatamisel saadi küll suure eluskaaluga lihavad lehmad, kuid tavalistes söötmistingimustes osutus nende jõudlusvõime lüpsiperioodidel ainult keskpäraseks või isegi puudulikuks $(3000-3500 \mathrm{~kg}$ piima aastas).

Nagu kõnesolevate katsete põhjal selgus, kasvasid võrdlemisi head piimalehmad C-rühmas, kus vasikate ööpäevased kaaluiibed kuni 6 kuuni moodustasid vaid $635 \mathrm{~g}$. Kõrgema väärtusega tõuloomade saamiseks, samuti varavalmimise kiirendamiseks on siiski soovitav, et eesti punast tõugu vasikate äöpäevased kaaluiibed kuni 6 kuuni moodustaksid 650 $700 \mathrm{~g}, 6-12$ kuuni $550-600 \mathrm{~g}$ ja teisel eluaastal $450-500 \mathrm{~g}$. Katsete pōhjal selgus, et põhisöötade puuduliku kvaliteedi tōttu üldiselt vähenes söötade tarbimine mõõduka täispiimanormi puhul. Sellega kaasus esialgu loomade aeglasem kasv, mis hiljem aga taastus.

Meie varasemad, enne Teist maailmasõda tehtud tähelepanekud näitasid, et kui joodeti vasika kohta $100-150 \mathrm{~kg}$ täispiima ja küllaldaselt lõssi, võis teiste rahuldavate söötmis- ja pidamistingimuste korral edukalt noorkarja kasvatada (mullikaid paaritati 20-kuuselt, täiskasvanud lehmade eluskaal oli umbes $550 \mathrm{~kg}$, aastane piimatoodang $4500-5000 \mathrm{~kg}$ ). Seejuures joodeti lõss vasikatele värskelt, soojalt ning puhtalt, lisades talle üksnes teatava koguse linaseemnekeedist.

1957. aastal Väimela zoo-veterinaartehnikumis alustatud ja praegu jätkuvad katsed näitavad, et manustades vasikatele $130 \mathrm{~kg}$ täispiima, $700 \mathrm{~kg}$ lõssi ja küllaldaselt hea kvaliteediga põhisöötasid, moodustab nende eluskaal 6-kuuselt $140 \mathrm{~kg}$, aasta vanuselt $230 \mathrm{~kg}$, mis vastab boniteerimisel I klassi nõudeile. Järelikult on põhjust arvata, et neist kasvavad sama hea kehaehitusega ja samasuguse jõudlusvõimega piimalehmad kui rühmades A, B, C ja D.

Vabariigi kolhoosides ja sovhoosides toodetakse vasikate jaoks veel vähe kõrge kvaliteediga vitamiinheina, mahlakaid söötasid, spetsiaalseid jõusöödasegusid. Kultuurkoplid pole alati täiesti rahuldavas seisundis ja piimakombinaatidest väljastatav lõss on sageli madala kvaliteediga. Noor. karja eduka ning ökonoomse kasvatamise huvides peaks nende puuduste kõrvaldamine olema ligemate aastate vältimatuks ülesandeks. Tähelepanu väärib Rapla rajooni «Uue Elu» kolhoosi algatus manustada vasikatele nii täispiima kui ka lõssi alati korralikult hapendatult, nn. kultuurhapupiimana.

Esitatud asjaolusid silmas pidades ei saa praegu soovitada täispiimanormi vähendamist vasika kohta alla $200-250 \mathrm{~kg}$. Vabariigi sovhoosides varem kasutatud kõrged täispiimanormid $(450-800 \mathrm{~kg})$ ei õigusta end ei bioloogiliselt ega majanduslikult. Ule $300-350 \mathrm{~kg}$ pole enamasti otstarbekas vasikatele täispiima joota; lõssinorm $500-800 \mathrm{~kg}$ näib olevat küllaldane.

Mõõduka, eriti aga madalama täispiima- ja lõssikoguse kasutamisel peaks noorveistele normaalse arenemise kindlustamiseks antama hea 
kvaliteediga põhisöötasid vastavalt nende tarbele ${ }^{[1]}$. Toitainete parema seedimise ja assimileerimise huvides on soovitav, et talvistes ratsioonides oleks mahlakail söötadel senisest suurem osatähtsus, kuna suvel pandagu pearõhk selles suhtes kultuurkarjamalarohule vegetatsiooni esimeses faasis $\left[{ }^{9-11}\right]$. Peetagu silmas, et mida varem ja paremini areneb vasikaeas välja põhisöötade kasutamisvõime, mida kiiremini kohaneb looma organism heina, silo ja karjamaasöödaga, seda ökonoomsem on noorkarja kasvatamine ja seda suutelisemad on lehmad andma kõrgeid piimatoodanguid kohalikul söödabaasil.

\section{Kokkuvõte ja järeldusi}

Milline mõju on suurtel või mõõdukatel täispiima- ja lõssikogustel vasikate ja mullikate kasvule, samuti täiskasvanud lehmade kehaehituse arenemisele ja jõudlusvõimele, selle väljaselgitamiseks korraldati katsed 35 eesti punast tõugu noorveisega, vanuses sünnist kuni III-IV laktatsiooniperioodi lõpuni. Katseloomad jagunesid 4 rühma, igasse 8-10 noorveist.

Erinevates rühmades kulutati vasika kohta $271-566 \mathrm{~kg}$ täispiima ja kuni 1330 kg lõssi. Maksimaalse täispiimanormi puhul lõssi ei antud.

Põhisöötade puuduliku kvaliteedi tõttu tarbisid kuni 6-kuused mõõduka täispiima- ja lõssikogusega söödetud vasikad neid $28-48 \%$ vähem, mistõttu nad jäid eluskaalult kuni 80 kg võrra kergemaks suurte piimanormidega toidetud vasikaist.

Aasta vanuselt jäid mõõduka täispiimanormiga kasvatatud noorveised boniteerimisel madalama eluskaalu tõttu II klassi, rohkem täispiima ja lōssi saanud rühmades ületas loomade eluskaal eliitrekordklassi taseme $11-14 \%$ võrra. Teisel eluaastal ja hiljem kompenseerus selline mahajäämus täiesti.

Olenevalt arengust paaritati mullikad kõigis rühmades $18,0-21,5$ kuuselt, eluskaaluga $360-400 \mathrm{~kg}$.

Sünnist kuni esmakordse poegimiseni söödeti looma kohta 3399-3926 söötühikut, mis sisaldas $414-463 \mathrm{~kg}$ seeduvat proteiini.

5 aasta vanuselt moodustas lehmade keskmine eluskaal erinevates katserühmades $519-560 \mathrm{~kg}$, mis vastab antud tõu puhul eliitrekordklassi nõudeile. Kehalise arengu poolest osutusid kõikide rühmade lehmad enamvähem võrdseks, vaatamata vasikaeas kasutatud erinevale täispiimanormile ja sellest olenevalt erisugusele kasvukiirusele. Kaalult raskemaks osutusid lehmad neis rühmades, kus nad paaritati mõnevõrra hilisemas eas (21,1-21,5 kuuselt).

Normikohasel söötmisel, vastavalt lehmade eluskaalule ja jõudlusvõimele, kõikusid üksikute rühmade piimatoodangud esimesel lüpsiperioodil (300 päeva jooksul) keskmiselt 3075 - 3499 kg piirides; piimarasvatoodang moodustas $114,1-138,2 \mathrm{~kg}$. Teisel lüpsiperioodil olid vastavad näitajad $3200-4146 \mathrm{~kg}$ ja 132,2 - $162,5 \mathrm{~kg}$, kolmandal $3486-4917 \mathrm{~kg}$ ja $141,2-$ $186,8 \mathrm{~kg}$, neljandal $4282-4642$ ja $157,6-177,8 \mathrm{~kg}$.

Paremate lehmade piimatoodangud I, II, III ja IV laktatsiooniperioodil ulatusid vastavalt 4856, 5128, 6708 ja $5923 \mathrm{~kg}-\mathrm{ni}$, piimarasvakogus aga $182,7,194,6,235,8$ ja 213,2 kg-ni.

Vôrreldes emadega olid A-, B- ja C-rühma lehmade piimatoodang $5-36 \%$ ja piimarasvasus $0,27-0,43 \%$ kōrgemad. D-rühma lehmade piimatoodang oli ligikaudu võrdne nende emadega, kuid piimarasvasus oli neil märgatiavalt kõrgem $(0,54 \%)$.

Meie katsed näitasid, et lehmade piima- ja piimarasvatoodang ei olenenud neile vasikaeas joodetud täispiimakogusest, vaid peamiselt nende 
erinevast vanusest esmakordsel paaritamisel. $21,1-21,5$ kuuselt paaritatud loomad andsid kolmel esimesel lüpsiperioodil rohkem piima ja piimarasva kui $18-18,5$ kuuselt paritatud, vaatamata nende kasvatamisel kulutatud täispiima- ja lõssikogusele.

Täiendavates katsetes selgus, et $130 \mathrm{~kg}$ täispiimaga ja $700 \mathrm{~kg}$ lõssiga üleskasvatatud vasikate eluskaalud vastavad I boniteerimisklassi nôudeile, kui neile tarbe kohaselt anda häid põhisöötasid.

Praeguste söötmis- ja pidamistingimuste juures enamikus vabariigi kolhoosides ja sovhoosides ei ole soovitav vähendada vasikatele antavat täispiimanormi alla $200-250 \mathrm{~kg}$. Täispiima kasutamiseks üle $300-350 \mathrm{~kg}$ vasika kohta pole aga bioloogilist vajadust. Ka lehmade jõudlusvõime tõstmise ja veisekasvatuse rentaabluse huvides ei anna see mingisuguseid märgataviaid tulemusi. Lõssinormina võib 500 - $800 \mathrm{~kg}$ pidada küllaldaseks.

\section{KIRJANDUS}

1. Arandi, P., Uued söötmisnormid ja -skeemid eesti punast tôugu noorkarjale. Tallinn, 1956.

2. Bonnier, E., Hansson, A. and Skjervold, H., Studies on Monozygons. Cattle Twin, IX. The Interplay of Heredity and Environment on Growth and Yield. Acta Agriculturae Suecana, 1948, 3, 1.

3. $\mathrm{H}$ a $\mathrm{ln}$ a n, S. T. and $\mathrm{G}$ a $\mathrm{rner}, \mathrm{F}$. H., The Principles and Practice of Feeding Farm Animals. London, New York, 1953.

4. Keevallik, E., S ärev, M. ja V a her, L., Eesti NSV Teaduste Akadeemia Loomakasvatuse ja Veterinaaria Instituudi Vändra katsejaam. Tallinn, 1954.

5. Korkman, N., Animal Breeding Research in Sweden. Anim. Breed. Abstr., 1954, $22,4$.

6. Le ig hto n, R. E. and R u pe1, J. W., A Simple Milk-Replacer Formula for Dairy Calves. J. Dairy Sci., $1955,38,6$.

7. S nook, A. C., Rearing Calves without Milk. J. Dept. Agric. W. Australia, 1955, 4, 2.

8. W a 11 a ge, H. D., Loos 1 i, S. K. and Türk, K. L., Milk Substitutes for Young Dairy Calves. J. Dairy Sci., 1949, 39, 8.

9. А р а нд и П. Я., Переваримость питательных веществ рацнонов молодняком эстонской красной породы скота в зависимости от типа н уровня кормления. Из. вестия АН ЭССР, т. III, 1954, № 3 .

10. А р анди П. Я., Усвояемость азота протеина корма молодняком крупного рога того скота эстонской красной породы. Известия АІІ ЭССР, т. III, 1954, № 4

11. А р а нд и П. Я., Усвояемость кальция и фосфора молодняком крупного poraтoro скота эстонской красной породы при различных по структуре и составу рационах. Известия АН ЭССР, т. IV, 1955, № 2.

12. Б е р з и н ь Я. М., Новый метод выращивания телят при небольших дачах цельного молока. Латгосиздат, 1954.

13. Д е м че н к о П. В., Выращивание телят в профилакторный период. В кн. «ередовой опыт по выращиванию телят». Сельхозгиз. Москва, 1955.

14. Д е м ч ен ко П. В., Повышение скороспелости крупного рогатого скота. Тр. Всес н.-н. ин-та кормлення сельскохозяйственных животных, т. III, Москва, 1956.

15. К руглов А. И., Влияние условий выращивания на развитие и продуктивность ярославского скота. В книге «Выращивание молодняка крупного poratoro скота». Сельхозгиз. Москва, 1956.

16. Обухов а А. Д., Опыт выращивания первотелок с высокой продуктивностью. Изв. ТСХА, вып. 1 (11), 1956.

17. Пш ен и ч н ы й П. Д., Основы учения о воспитании сельскохозяйственных животных. Изд-во АН Укр. ССР. Кнев, 1955.

18. Пше н и чны й П. Д., Научные основы выращивания сельскохозяйственных жи вотных. В книге «Выращивание молодняка крупного рогатого скота». Сельхозгиз. Москва, 1956.

19. Юрмалиат А. П., Бегучев А. П. и Бломквист М. С., Передовой опыт выращивания телят. Сельхозгиз. Москва, 1950.

Eesti Loomakasvatuse ja Veterinaaria Teadusliku Uurimise Instituut 


\title{
ЗНАЧЕНИЕ РАЗЛИЧНОГО КОЛИЧЕСТВА ЦЕЛЬНОГО МОЛОКА ПРИ ВЫПОИКЕ ТЕЛЯТ НА РАЗВИТИЕ ТЕЛОСЛОЖЕНИЯ И ПОСЛЕДУЮЩУЮ ПРОДУКТИВНОСТЬ КОРОВ
}

\author{
П. Я. Аранди, \\ доктор сельскохозяйственных наук
}

\section{Резюме}

Цель опытов заключалась в выяснении влияния обильных и умеренных дач цельного молока (различных количеств молочного жира) на рост и развитие телят, а также на телосложение и молочную продуктивность коров. Под опытом находилось 35 телок эстонской красной породы со дня рождения до конца III-IV лактации. Все они подразделялись на четыре группы (группы А, B, С, D), по 8-10 животных в каждой.

На теленка было выпоено цельного молока: в группе А - $306 \mathrm{kr}$, В - 566, C - 271, D - $460 \mathrm{kr}$, что составляет соответственно 11,2, 20,9, 9,98 и 16,7 кг молочного жира. Телята трех групп (кроме группы В) получили обрат в количестве от 810 (группа C) до $1330 \mathrm{kr}$ (группа D). В течение всего периода выращивания молодняк всех групп грубых и зеленых кормов получал вволю, концентраты нормировались, исходя из норм молочных кормов. Со дня рождения и до 2-летнего возраста на одно животное в различных группах было фактически израсходовано от 2589 (группа В) до 2822 (группа А) кормовых единиц и от 285 до 321 кг переваримого протеина (на основе точного индивидуального учета и изучения химического состава съеденных кормов).

В силу недостаточно высокого качества грубых и сочных кормов (отсутствие витаминного сена и т. п.), телята группы С потребили до 6-месячного возраста на 28$48 \%$ меньше питательных веществ, чем остальные.

При бонитировке в годовалом возрасте живой вес животных группы С отвечал требованиям II класса, а в остальных превышал требования класса элита-рекорд на $11-14 \%$. На втором году и позже отставание в росте и развитии вполне восстанавливалось.

В зависимости от развития телок их первое спаривание осуществлялось в различных группах в возрасте от 18,0 (группы А и D) до 21,5 (группы В и С) месяцев при среднем весе животных $360-400$ кг.

В 5-летнем возрасте средний живой вес коров во всех группах составил от 519 до $560 \mathrm{kr}$, что отвечает требованиям класса элита-рекорд по данной породе. Несмотря на израсходование различного количества цельного молока (молочного жира) и различную скорость роста в молодом возрасте, животные всех групп имели практически одинаково хорошо развитое телосложение. Несколько больший вес имели животные в группах В и С, в которых первое спаривание проводилось в позднем возрасте (в $21,1-21,5$ месяцев).

При кормлении по нормам (на основе живого веса и фактической продуктивности) средняя продуктивность на корову в различных группах была следующей:

\begin{tabular}{c|c|c|c|c|c}
\hline \multirow{2}{*}{ Группа } & $\begin{array}{c}\text { Лакта- } \\
\text { ция }\end{array}$ & $\begin{array}{c}\text { Число } \\
\text { коров }\end{array}$ & $\begin{array}{c}\text { Средняя продуктивность } \\
\text { молока за } 300 \text { дней в кг }\end{array}$ & $\begin{array}{c}\text { Средняя жирность молока } \\
\text { в \%* }\end{array}$ \\
\hline \multirow{5}{*}{ A } & I & 8 & $3163(2042-4245)$ & $3,78(3,31-3,85)$ \\
& II & 6 & $3708(2590-4641)$ & $3,69(3,49-3,87)$ \\
& III & 6 & $3906(2832-4916)$ & $3,89(3,54-4,36)$ \\
& IV & 5 & $4282(3338-5054)$ & $3,68(3,61-4,08)$ \\
B & I & 8 & $3499(3187-4425)$ & $3,95(3,44-4,46)$ \\
& II & 6 & $4146(3576-5128)$ & $3,92(3,54-4,41)$ \\
& III & 5 & $4125(3253-5445)$ & $4,11(3,73-4,91)$ \\
C & IV & 5 & $4642(3554-5923)$ & $3,82(3,50-4,42)$ \\
& I & 10 & $3380(2307-4856)$ & $3,66(3,47-4,18)$ \\
& II & 10 & $3798(2139-5010)$ & $3,85(3,27-4,27)$ \\
D & III & 6 & $4917(3770-6708)$ & $3,80(3,42-4,44)$ \\
& I & 8 & $3075(2763-3454)$ & $3,71(3,65-4,06)$ \\
& II & 6 & $3200(2772-3800)$ & $4,13(3,72-4,43)$ \\
& III & 4 & $3486(2618-4113)$ & $4,05(3,80-4,26)$
\end{tabular}

* В скобках указаны колебания. 
По сравнению с матерями продуктивность в группах А, В и С оказалась выше: по молоку от 5 (группа A) до 36 (группа С) процентов, по содержанию жира на $0,27-0,43 \%$. По удою молока группа D примерно равнялась матерям, но по содержанию жира в молоке - превышала последние на $0,54 \%$.

Продуктивность коров в этих опытах, по-видимому, не была обусловлена выпоенным в период выращивания количеством цельного молока (молочного жира).

Коровы, покрытые в возрасте 21,1-21,5 месяцев, давали в первые лактации (до III лактащии включительно) больше молока и молочного жира, чем спаренные в $18-18,5$ месяцев.

Начатые в 1957 г. дополнительные опыты показывают, что при норме цельного и снятого молока соответственно в 130 и $700 \mathrm{kr}$ (при высоком качестве вволю скармливаемых грубых и сочных кормов) живой вес телят составляет в 6-месячном во3расте $140 \mathrm{kr}$ и в годовалом возрасте $230 \mathrm{kr}$, т. е. соответствует 1 классу по данной породе.

В существующих условиях кормления и содержания молодняка в ЭССР (нехватка хороших основных кормов, недостаточно высокое качество снятого молока и др.) норму цельного молока на теленка не рекомендуется назначать ниже $200-250$ кг. Скармливание свыше 300-350 кг цельного молока на теленка не оправдывает себя ни с биологической, ни с экономической точек зрения. Что касается снятого молока, то можно считать, что скармливание $500-800$ кг такового на животное является достаточным.

В статье обсуждаются также вопросы о возможностях дальнейшего сокращения нормы цельного молока на выпойку телят и задачи по рациональному кормлению молодняка в будущем.

\title{
Эстонский научно-исследовательский институт животноводства и ветеринарии
}

Поступила в редакцию 22 XI 1957

\section{INFLUENCE OF THE ALLOWANCE OF WHOLE MILK GIVEN TO CALVES ON BODY DEVELOPMENT AND MILK PRODUCTION OF THE COWS}

\author{
P. Arandi
}

\section{Summary}

In order to find out the importance of large and moderate norms of whole and skim milk on the body development of calves and heifers and their subsequent milk production. the author carried out experiments with 35 calves and heifers of the Estonian Red Breed from birth up to the third or the fourth lactation period, respectively. The experimental animals were divided into four experimental groups (A, B, C, D) of 8-10 young animals each.

The average amount of whole milk given to a cali was in Group $\mathrm{A}-306 \mathrm{~kg}$, in Group B - $566 \mathrm{~kg}$, in Group C - 271 kg, and in Group D -- $460 \mathrm{~kg}$, corresponding to $11.2,20.9,9.98$ and $16.7 \mathrm{~kg}$ of milk fat respectively. All the groups (with the exception of Group B) received from $810 \mathrm{~kg}$ (Group C) to $1330 \mathrm{~kg}$ (Group D) of skim milk. The calves in all the groups had their fill of rough and green fodders over the whole period of growth, concentrates were rationed according to the amount of whole and skim milk given From birth up to the age of two years the animals in the different groups received 2589 (in Group B) up to 2822 feed-units (in Group A) and 285 up to $321 \mathrm{~kg}$ of digestible proteins on an average per animal.

$\mathrm{O}_{n}$ account of the deficient quality of the rough and succulent fodders (lack of vitamin hay, etc.) the calves in Group C (up to 6 months of age) consumed 28-48 per cent less nutrients than the rest of the calves.

Evaluation of calves on the basis of body development at the age of a year gave different results: the live weight oi the calves who had been receiving moderate amounts of whole milk fulfilled the requirements of the second class; in the other groups the live weight of the calves which had been receiving larger amounts of whole and skim milk exceeded the requirements of the élite record class by 11 to 14 per cent. Backwardness was fully compensated in the second year of life and later.

The coupling of heifers in the different experimental groups was carried out in dependence on their body development at the age of 18.0 months (in Groups A and D) up to 21.5 months (in Groups B and C) with the average live weight of $360-400 \mathrm{~kg}$. 
At the age of five years the average live weight of a cow in the different experimental groups varied from 519 to $560 \mathrm{~kg}$, which in the case of the given breed corresponds to the requirements of the élite record class. In body development the cows of all the experimental groups were more or less equal, irrespective of different amounts of whole milk given to them and the different rate of their growth. The cows of the groups $\mathrm{B}$ and $\mathrm{C}$ in which coupling was carried out at a more advanced age (21.1-21.5 months) were somewhat heavier.

Under the normal feeding conditions corresponding to the live weight and the actual milk production of the experimental animals the average milk yields per cow are as follows:

\begin{tabular}{|c|c|c|c|c|}
\hline Group & Lactation & $\begin{array}{l}\text { Number } \\
\text { of cows }\end{array}$ & $\begin{array}{c}\text { Average pecentage of } \\
\text { milk fat } \\
\text { (fluctuations are indica- } \\
\text { ted in brackets) }\end{array}$ & $\begin{array}{c}\text { Average milk production } \\
\text { during } 300 \text { days in kilo- } \\
\text { grams } \\
\text { (fluctuations are indi- } \\
\text { cated in brackets) }\end{array}$ \\
\hline A & $\begin{array}{l}\text { I } \\
\text { II } \\
\text { III } \\
\text { IV }\end{array}$ & $\begin{array}{l}8 \\
6 \\
6 \\
5\end{array}$ & $\begin{array}{l}3,78(3,31-3,85) \\
3,69(3,49-3,87) \\
3,89(3,54-4,36) \\
3,68 \quad(3,61-4,08)\end{array}$ & $\begin{array}{ll}3163 & (2042-4245) \\
3708 & (2590-4641) \\
3906 & (2832-4916) \\
4282 & (3338-5054)\end{array}$ \\
\hline B & $\begin{array}{l}\text { I } \\
\text { II } \\
\text { III } \\
\text { IV }\end{array}$ & $\begin{array}{l}8 \\
6 \\
5 \\
5\end{array}$ & $\begin{array}{ll}3,95 & (3,44-4,46) \\
3,92 & (3,54-4,41) \\
4,11 & (3,73-4,91) \\
3,82 & (3,50-4,42)\end{array}$ & $\begin{array}{ll}3499 & (3187-4425) \\
4146 & (3576-5128) \\
4125 & (3253-5445) \\
4642 & (3554-5923)\end{array}$ \\
\hline C & $\begin{array}{r}\text { I } \\
\text { II } \\
\text { III }\end{array}$ & $\begin{array}{r}10 \\
10 \\
6\end{array}$ & $\begin{array}{ll}3,66 & (3,47-4,18) \\
3,85 & (3,27-4,27) \\
3,80 & (3,42-4,44)\end{array}$ & $\begin{array}{ll}3380 & (2307-4856) \\
3798 & (2139-5010) \\
4917 & (3770-6708)\end{array}$ \\
\hline D & $\begin{array}{r}\text { I } \\
\text { II } \\
\text { III }\end{array}$ & $\begin{array}{l}8 \\
6 \\
4\end{array}$ & $\begin{array}{ll}3,71 & (3,65-4,06) \\
4,13 & (3,72-4,43) \\
4,05 & (3,80-4,26)\end{array}$ & $\begin{array}{l}3075(2763-3454) \\
3200(2772-3800) \\
3486(2618-4113)\end{array}$ \\
\hline
\end{tabular}

The yield of milk and milk fat of the cows tested evidently did not depend on the amount of the whole milk (i. e. the quantity of the milk fat) given to calves and on the speed of their growth in youth, but chiefly on the different age of the animals at the first coupling.

The heifers coupled at the age of $21-21.5$ months gave more milk and milk fat during the first lactation periods than the groups of heifers coupled at the age of 18 18.5 months.

Additional experiments that commenced in 1957 showed that when calves were given only $130 \mathrm{~kg}$ of whole milk and $700 \mathrm{~kg}$ of skim milk (by feeding them sufficient quantities of basic fodder of good quality) their live weight at the age of 6 months was $140 \mathrm{~kg}$, and at the age of 12 months $230 \mathrm{~kg}$, and thus corresponded to the requirements of the first class for this breed.

In the feeding and keeping conditions prevailing at present in the Estonian Soviet Republic (sufficient quantity of the basic fodder, deficient quality of the skim milk, etc.) one cannot recommend to give the calves less than $250 \mathrm{~kg}$ of whole milk. To give the calves over $300-350 \mathrm{~kg}$ of whole milk is biologically and economically unfounded. The amount of skim milk within the limits of $500-800 \mathrm{~kg}$ can be considered sufficient.

By way of discussion the author also deals with the question of the necessary conditions and the possibility of a further cutting down of the amount of whole milk in the rearing of calves, and with the tasks of organisation of rational feeding of young animals in the future.

The Estonian Scientific Research Institute of Livestock-Breeding and Veterinary Medicine
Received Nov. 22, 1957 